ISSN: 2302-8556

\title{
Pengaruh Likuiditas, Pertumbuhan Penjualan, dan Risiko Bisnis terhadap Nilai Perusahaan
}

\author{
Ida Ayu Puspita Trisna Dewi ${ }^{1}$ \\ I Ketut Sujana ${ }^{2}$ \\ ${ }^{1,2}$ Fakultas Ekonomi dan Bisnis Universitas Udayana (Unud), Bali, Indonesia \\ e-mail: dayutrisnadewi1994@yahoo.com
}

\begin{abstract}
ABSTRAK
Penelitian ini bertujuan menganalisis pengaruh Likuiditas, Pertumbuhan Penjualan, dan Risiko Bisnis terhadap Nilai Perusahaan (studi pada Perusahaan Telekomunikasi yang terdaftar di Bursa Efek Indonesia periode 2011-2016). Populasi penelitian meliputi seluruh perusahaan telekomunikasi yang terdaftar di Bursa Efek Indonesia periode 2011-2016. Data populasi penelitian sebanyak 30 perusahaan dengan sampel pengamatan sebanyak 5 perusahaan. Metode yang digunakan pada penelitian ini adalah metode purposive sampling. Analisis data diuji dengan menggunakan analisis regresi linier berganda. Hasil penelitian ini menunjukan bahwa likuiditas berpengaruh positif terhadap nilai perusahaan, pertumbuhan penjualan berpengaruh positif terhadap nilai perusahaan dan risiko bisnis berpengaruh negatif terhadap nilai perusahaan.

Kata kunci: likuiditas, pertumbuhan penjualan, risiko bisnis dan nilai perusahaan
\end{abstract}

\begin{abstract}
This study aims to analyze the effect of Liquidity, Sales Growth, and Business Risk to Company Value (study on Telecommunication Company listed on Indonesia Stock Exchange period 2011-2016). The study population includes all telecommunication companies listed on Indonesia Stock Exchange period 2011-2016. The research population data are 30 companies with observation samples of 5 companies. The method used in this research is purposive sampling method. Data analysis was tested by using multiple linear regression analysis. The results of this study indicate that liquidity has a positive effect on corporate value, sales growth positively affect the value of the company and business risk negatively affect the value of the company.

Keywords: liquidity, sales growth, business risk and corporate value
\end{abstract}

\section{PENDAHULUAN}

Berdirinya sebuah perusahaan harus memiliki tujuan yang jelas. Ada beberapa hal yang mengemukakan tujuan dari berdirinya sebuah perusahaan. Tujuan yang pertama adalah untuk mencapai keuntungan maksimal. Tujuan yang kedua adalah ingin memakmurkan pemilik perusahaan atau para pemilik saham. Sedangkan tujuan perusahaan yang ketiga adalah memaksimalkan nilai perusahaan yang tercermin pada harga sahamnya. Ketiga tujuan perusahaan tersebut sebenarnya 
secara substansial tidak banyak berbeda. Hanya saja penekanan yang ingin dicapai oleh masing-masing perusahaan berbeda antara yang satu dengan yang lainnya (Harjito dan Martono (2005) dalam Mahendra (2011:1).

Nilai perusahaan merupakan persepsi investor terhadap suatu perusahaan yang berkaitan dengan harga saham. Suatu perusahaan dikatakan mempunyai nilai yang baik jika kinerja perusahaan juga baik. Semakin tinggi harga saham, maka semakin tinggi pula nilai perusahaan. Nilai perusahaan yang tinggi menjadi keinginan para pemilik perusahaan, sebab dengan nilai yang tinggi menunjukan kemakmuran pemegang saham juga tinggi. Investor juga cenderung lebih tertarik menanamkan sahamnya pada perusahaan yang memiliki kinerja yang baik dalam meningkatkan nilai perusahaan. Pada penelitian ini nilai perusahaan dapat diproksikan dengan menggunakan Price Book Value (PBV).

Nilai perusahaan dapat dicapai dengan maksimum jika para pemegang saham menyerahkan urusan pengelolaan perusahaan kepada orang-orang yang berkompeten dalam bidangnya, seperti manajer maupun komisaris. Nilai perusahaan yang baik akan dapat menarik lebih banyak investor dan kepentingan pihak lain untuk ikut serta dalam perusahaan. Jadi, penting untuk menentukan dulu nilai perusahaan perusahaan untuk investasi yang andal (Sucuahi et al. 2016). Namun, dalam meningkatkan nilai perusahaan akan muncul masalah kepentingan antara agen (manajer) dan principal (pemegan saham). Tidak jarang manajer perusahaan mempunyai tujuan dan kepentingan lain yang bertentangan dengan tujuan utama perusahaan dan sering mengabaikan kepentingan pemegang saham. 
ISSN: 2302-8556

Perbedaan kepentingan antara manajer dan pemegang saham ini mengakibatkan timbulnya konflik yang biasa disebut agency conflict, hal tersebut terjadi karena manajer lebih mengutamakan kepentingan pribadinya sebaliknya pemegang saham tidak menyukai kepentingan pribadi dari manajer karena apa yang dilakukan manajer tersebut akan menambah biaya bagi perusahaan sehingga menyebabkan penurunan keuntungan perusahaan dan berpengaruh terhadap harga saham sehingga menurunkan nilai perusahaan (Meckling, 1976).

Adanya agency conflict seringkali lebih merugikan investor dikarenakan kepemilikan informasi oleh investor lebih sedikit dibandingkan manajer atau yang biasa disebut sebagai asimetri informasi. Akibatnya pihak investor akan melindungi dirinya dengan memberikan harga yang rendah bagi perusahaan (Arif, 2015). Oleh karena itu, perusahaan harus mengurangi asimetri informasi dengan memberikan sinyal positif bagi pihak investor, berupa laporan keuangan yang dapat dipercaya dan menunjukkan prospek perusahaan yang cerah (Arif, 2015).

Faktor yang mempengaruhi nilai perusahaan adalah likuiditas yang merupakan kemampuan suatu perusahaan untuk memenuhi kewajiban keuangannya dalam jangka pendek atau yang segera dibayar (Riyanto, 2001:25). Perusahaan yang mampu memenuhi kewajiban keuangannya tepat waktu berarti perusahaan tersebut dalam keadaan likuid atau dengan kata lain perusahaan tersebut mempunyai alat pembayaran ataupun aset lancar yang lebih besar daripada utang lancar atau utang jangka pendek (Munawir, 2004:31). Alat pembayaran kewajiban keuangan jangka pendek ini berasal dari unsur-unsur aset 
yang bersifat likuid, yaitu aset lancar dengan perputaran kurang dari satu tahun, karena lebih mudah dicairkan daripada aset tetap yang perputarannya lebih dari satu tahun (Harahap, 2010:301). Hal ini didukung oleh hasil penelitian Menawati (2017) menyatakan pengaruh positif likuiditas terhadap nilai perusahaan. Pada penelitian ini likuiditas dapat diproksikan dengan menggunakan current ratio.

Pertumbuhan penjualan juga menjadi faktor yang mempengaruhi nilai perusahaan. Pertumbuhan penjualan dapat diartikan sebagai kenaikan jumlah penjualan dari tahun ke tahun atau dari periode ke periode. Pertumbuhan penjualan mencerminkan keberhasilan investasi periode masa lalu dan dapat dijadikan sebagai prediksi pertumbuhan masa yang akan datang (Barton et al., 1989) dalam (Mardiyati et al., 2015). Pertumbuhan suatu perusahaan dapat dilihat dari bertambahnya volume penjualan. Dengan meningkatkan volume penjualan, maka perusahaan dapat meningkatkan perolehan pendapatan dan laba perusahaan, sehingga perusahaan dapat menutup biaya-biaya yang dikeluarkan untuk operasional perusahaan. Pertumbuhan penjualan merupakan indikator permintaan dan daya saing perusahaan dalam suatu industri. Laju pertumbuhan suatu perusahaan akan mempengaruhi kemampuan mempertahankan keuntungan dalam menandai kesempatan-kesempatan pada masa yang akan datang. Hal ini didukung oleh hasil penelitian Sukaria (2015) menyatakan bahwa pertumbuhan penjualan berpengaruh positif terhadap nilai perusahaan. Pada penelitian ini, pertumbuhan penjualan diproksikan dengan membandingkan penjualan pada tahun ke-t setelah dikurangi penjualan periode sebelumnya. 
ISSN: 2302-8556

Faktor berikutnya yang mempengaruhi nilai perusahaan adalah risiko bisnis. Weston (1996) menyatakan risiko bisnis adalah ketidakpastian dalam proyeksi perusahaan atas tingkat pengembalian atau laba di masa mendatang. Dalam suatu perusahaan, risiko bisnis meningkat jika menggunakan utang yang tinggi. Brigham dan Houston (2006) menyatakan perusahaan yang memiliki risiko bisnis tinggi, akan meningkatkan penggunaan utang sebagai sumber pendanaan. Selain itu, risiko bisnis yang besar menyebabkan kreditur enggan untuk memberikan pinjaman dan investor juga enggan untuk menanamkan modal ke perusahaan. Hal ini dikarenakan mereka khawatir dana yang diberikan kepada perusahaan tidak dapat dikembalikan oleh perusahaan atau tidak menghasilkan keuntungan. Hal ini didukung oleh hasil penelitian Bayless dan Diltz (1994) yang menemukan hubungan negatif antara risiko bisnis dengan utang. Pada penelitian ini, risiko bisnis dapat diproksikan dengan standar deviasi EBIT yang menggunakan data keuangan perusahaan 6 (enam) tahun sebelumnya.

Penelitian ini akan dilakukan pada sektor telekomunikasi yang terdaftar di Bursa Efek Indonesia Periode 2011-2016. Hal ini dikarenakan perusahaan telekomunikasi merupakan salah satu perusahaan yang paling dinamis. Seiring perkembangan perubahan teknologi, kebutuhan atas obyek-obyek yang terkait dalam sektor telekomunikasi, seperti Handphone terus mengalami pergeseran dari yang awalnya merupakan kebutuhan tersier, berubah menjadi kebutuhan sekunder, dan akhir-akhir ini dapat dikategorikan menjadi kebutuhan primer bagi masyarakat khususnya Indonesia karena teknologi memudahkan aktivitas manusia 
dalam berkomunikasi dan bertukar informasi. Oleh karena itu, menarik bagi penulis untuk meneliti faktor-faktor penentu nilai perusahaan pada sektor telekomunikasi ini dengan mempertimbangkan variabel likuiditas, pertumbuhan penjualan dan risiko bisnis. Fenomena ini dapat dilihat dari rasio nilai perusahaan (PBV) perusahaan telekomunikasi sebagai berikut :

Tabel 1.

Rata-rata Price Book Value (PBV) Perusahaan Telekomunikasi Periode Tahun 2011-2016

\begin{tabular}{cc}
\hline Tahun & PBV \\
\hline 2011 & 3,87 \\
2012 & 2,91 \\
2013 & 4,17 \\
2014 & 1,42 \\
2015 & 1,51 \\
2016 & 1,46 \\
\hline
\end{tabular}

Sumber: Data diolah, 2017

Berdasarkan Tabel 1., dapat dilihat bahwa rasio PBV perusahaan telekomunikasi pada tahun 2011-2016 selalu berada di atas angka 1. Hal ini menunjukkan bahwa nilai perusahaan yang berfluktuasi tiap tahunnya dan mengalami tren penurunan seperti contoh pada tahun 2011 memiliki nilai perusahaan sebesar 3,87 namun pada tahun 2012 mengalami penurunan menjadi 2,91, pada tahun 2013 kembali mengalami peningkatan hingga 4,17 lalu kembali lagi mengalami penurunan dan penigkatan pada tahun 2014 dan tahun 2015, pada tahun terakhir 2016 price book value kembali menurun hingga 1,46. Berdasarkan fenomena diatas dapat diketahui terdapat beberapa faktor yang mempengaruhi nilai perusahaan yaitu salah satunya dari kurangnya kinerja yang optimal dan adanya persaingan antara perusahaan karena kondisi perekonomian yang tidak stabil sehingga mengalami fluktuasi disetiap tahunnya. 
ISSN: 2302-8556

Tujuan penelitian ini yaitu: 1) Untuk menguji secara empiris pengaruh likuiditas terhadap nilai perusahaan perusahaan telekomunikasi yang terdaftar di BEI periode 2011-2016; 2) Untuk menguji secara empiris pengaruh pertumbuhan penjualan terhadap nilai perusahaan perusahaan telekomunikasi yang terdaftar di BEI periode 2011-2016; 3) Untuk menguji secara empiris pengaruh risiko bisnis terhadap nilai perusahaan perusahaan telekomunikasi yang terdaftar di BEI periode 2011-2016.

Penelitian ini diharapkan dapat memberikan bukti empiris mengenai signaling theory dengan melihat pengaruh likuiditas, pertumbuhan penjualan dan risiko bisnis terhadap nilai perusahaan. Selain itu, diharapkan dapat memberikan tambahan ilmu pengetahuan dan informasi yang dapat dijadikan referensi peneliti lain dalam penelitian selanjutnya berkaitan dengan nilai perusahaan.

Teori sinyal mengemukakan tentang bagaimana seharusnya sebuah perusahaan memberikan sinyal kepada pengguna laporan keuangan. Brigham dan Houston (2001) menyatakan bahwa sinyal adalah suatu tindakan yang diambil oleh manajemen perusahaan yang memberikan petunjuk bagi investor tentang bagaimana manajemen memandang prospek perusahaan. Signaling theory yang dikemukakan oleh Bhattacharya (1979), yaitu pengumuman perubahan dividen mempunyai kandungan informasi yang mengakibatkan munculnya reaksi harga saham. Investor menilai perubahan dividen sebagai sinyal ramalan laba oleh manajemen. Perusahaan dengan prospek yang menguntungkan akan mencoba menghindari penjualan saham dan mengusahakan modal baru dengan cara-cara 
lain seperti dengan menggunakan utang. Hasnawati (2005) menyatakan dalam teori sinyal dijelaskan tentang hubungan antara pengeluaran investasi dan juga nilai perusahaan, dimana pengeluaran investasi memberikan sinyal positif tentang pertumbuhan perusahaan dimasa yang akan datang, sehingga dapat meningkatkan harga sebagai indikator nilai perusahaan. Susilowati dan Turyanto (2011) menyatakan teori sinyal ini membahas bagaimana seharusnya sinyal-sinyal keberhasilan atau kegagalan manajemen (agent) disampaikan kepada pemilik modal (principal).

Teori sinyal juga menjelaskan mengapa perusahaan mempunyai dorongan untuk memberikan informasi laporan keuangan pada pihak eksternal. Dorongan perusahaan untuk memberikan informasi karena terdapat asimetri informasi antara perusahaan dan pihak luar karena perusahaan mengetahui lebih banyak mengenai perusahaan dan prospek yang akan datang dari pihak luar. Kurangnya informasi bagi pihak luar mengenai perusahaan menyebabkan mereka melindungi diri mereka dengan memberikan harga yang rendah untuk perusahaan. Perusahaan dapat meningkatkan nilai perusahaan dengan mengurangi asimetri informasi. Salah satu cara mengurangi informasi asimetri adalah dengan memberikan sinyal pada pihak luar, salah satunya berupa informasi keuangan yang dapat dipercaya dan akan mengurangi ketidakpastian mengenai prospek perusahaan yang akan datang.

Rasio likuiditas digunakan untuk mengukur kemampuan perusahaan untuk memenuhi kewajiban jangka pendeknya (Van Horne dan Wachowicz, 1998). 
ISSN: 2302-8556

Suatu perusahaan yang likuiditasnya meningkat, lebih memilih untuk tidak menggunakan pinjaman (Joni dan Lina, 2010). Perusahaan mempunyai dorongan untuk memberikan informasi laporan keuangan pada pihak eksternal. Dorongan perusahaan untuk memberikan informasi karena terdapat asimetri informasi antara perusahaan dan pihak luar karena perusahaan mengetahui lebih banyak mengenai perusahaan dan prospek yang akan datang dari pihak luar. Perusahaan dapat meningkatkan nilai perusahaan dengan mengurangi asimetri informasi. Salah satu cara mengurangi informasi asimetri adalah dengan memberikan sinyal pada pihak luar, salah satunya berupa informasi keuangan yang dapat dipercaya dan akan mengurangi ketidakpastian mengenai prospek perusahaan yang akan datang.

Likuiditas yang tinggi dapat mempengaruhi investor untuk berinvestasi pada perusahaan sehingga permintaan saham perusahaan akan meningkat dan kemudian harganya naik. Kenaikan likuiditas meningkatkan nilai perusahaan, pembuat keputusan keuangan dianjurkan untuk menggunakan likuiditas yang tinggi demi nilai perusahaan lebih tinggi agar bisa memanfaatkan peluang investasi secara optimal (Alfi et al. 2016). Penelitian yang dilakukan oleh Menawati (2017) menemukan pengaruh positif likuiditas terhadap nilai perusahaan. Bila perusahaan mampu memelihara likuiditasnya dengan baik, maka kegiatan operasional perusahaan dapat berjalan dengan baik dan dapat memberikan dampak yang positif pada perusahaan.

$\mathrm{H}_{1}$ : Likuiditas berpengaruh positif terhadap nilai perusahaan 
Pertumbuhan penjualan menunjukkan perkembangan perusahaan. Suatu perusahaan yang mempunyai pertumbuhan penjualan tinggi mencerminkan perkembangan perusahaan tersebut tinggi (Barton et al. 1989) dalam (Mardiyati et al. 2015) . Menurut Brigham dan Houston (2001) perusahaan dengan tingkat penjualan relatif stabil apabila memperoleh lebih banyak pinjaman dan menanggung beban tetap yang lebih tinggi. Weston dan Brigham (1993) mengatakan perusahaan dengan tingkat pertumbuhan yang cepat harus lebih banyak menggunakan modal eksternal dengan mempertimbangkan floating cost yang ditanggung. Pertumbuhan penjualan merupakan indikator permintaan dan daya saing perusahaan dalam suatu industri. Laju pertumbuhan suatu perusahaan akan mempengaruhi kemampuan mempertahankan keuntungan dalam menandai kesempatan-kesempatan pada masa yang akan datang. Pertumbuhan penjualan yang tinggi maka akan mencerminkan pendapatan meningkat sehingga pembayaran deviden cenderung meningkat. Penelitian yang dilakukan oleh Sukaria (2015) menyatakan bahwa pertumbuhan penjualan berpengaruh positif terhadap nilai perusahaan. Hal ini berarti semakin tingggi pertumbuhan penjualan maka nilai perusahaan semakin meningkat atau sebaliknya semakin rendah pertumbuhan penjualan semakin rendah nilai perusahaan.

$\mathrm{H}_{2}$ : Pertumbuhan penjualan berpengaruh positif terhadap nilai perusahaan

Weston (1996) menyatakan risiko bisnis adalah ketidakpastian dalam proyeksi perusahaan atas tingkat pengembalian atau laba di masa mendatang. Perusahaan dengan risiko bisnis yang besar cenderung menggunakan hutang lebih 
ISSN: 2302-8556

kecil dibandingkan dengan perusahaan yang mempunyai risiko bisnis rendah, dikarenakan penggunaan hutang besar akan mempersulit perusahaan dalam mengembalikan hutang mereka. Selain itu, risiko bisnis yang besar menyebabkan kreditur enggan untuk memberikan pinjaman dan investor juga enggan untuk menanamkan modal ke perusahaan. Perusahaan yang memiliki risiko bisnis yang tinggi karena keputusan pendanaan yang dipilihnya menyebabkan nilai perusahaan turun dimata investor yang mempertimbangkan ketika terjadi risiko kebangkrutan, maka kebanyakan aset perusahaan akan dijual untuk melunasi hutang yang jumlahnya besar dibandingkan untuk mengembalikan nilai saham yang ditanamkan investor. Berdasarkan hasil penelitian dari Efni (2011), serta Pagach dan Warr (2010), risiko bisnis mempunyai pengaruh negatif terhadap nilai perusahaan. Hal ini berarti bahwa semakin meningkat risiko bisnis perusahaan maka nilai perusahaan akan semakin menurun.

$\mathrm{H}_{3}$ : Risiko Bisnis berpengaruh negatif pada nilai perusahaan

\section{METODE PENELITIAN}

Penelitian ini menggunakan pendekatan kuantitatif berbentuk asosiatif karena bersifat menghubungkan antara dua variabel atau lebih. Dikatakan kuantitatif karena data yang digunakan mempunyai satuan yang dapat diukur. Penelitian ini bertujuan untuk mengetahui pengaruh likuiditas, pertumbuhan penjualan, dan risiko bisnis terhadap nilai perusahaan perusahaan telekomunikasi yang terdaftar di Bursa Efek Indonesia periode 2011-2016. Berdasarkan permasalahan yang 
telah dikemukakan, kajian teoritis, dan tinjauan penelitian terdahulu, maka desain penelitian ini dapat disajikan dalam Gambar 1. sebagai berikut:

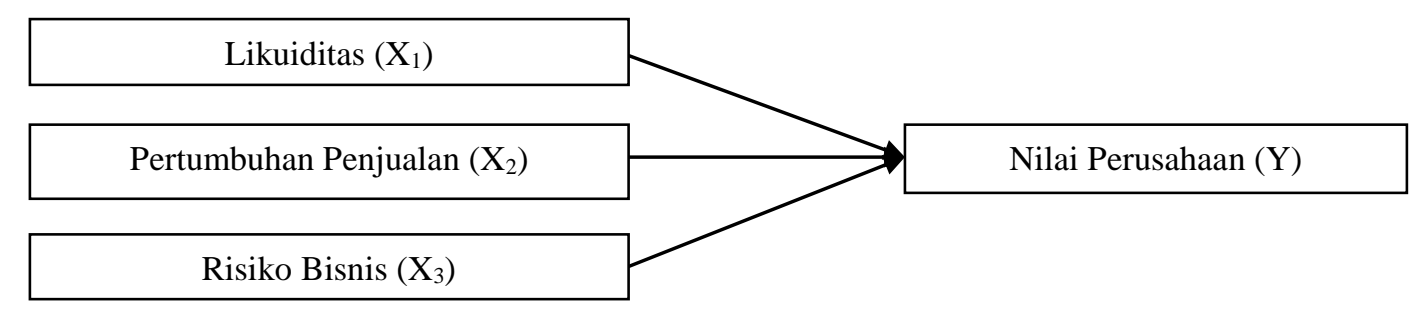

\section{Gambar 1. \\ Desain Penelitian}

Sumber: Data diolah, 2017

Penelitian ini mengambil sampel perusahaan-perusahaan Telekomunikasi yang terdaftar di Bursa Efek Indonesia (BEI). Penelitian ini dilakukan dengan mengambil data dari www.idx.co.id periode 2011-1016. Variabel terikat (dependent), yaitu variabel yang dipengaruhi atau yang menjadi akibat karena adanya variabel bebas (independent) (Sugiyono, 2013:59). Variabel terikat dalam penelitian ini adalah Nilai Perusahaan (Y). Nilai perusahaan adalah harga suatu perusahaan yang bersedia dibayar oleh investor apabila dijual (Suad Husnan, 2005; Wiagustini, 2010). Pada penelitian ini nilai perusahaan diproksikan dengan menggunakan Price Book Value (PBV). PBV adalah suatu rasio yang menunjukkan hubungan antara harga pasar saham perusahaan dengan nilai buku perusahaan (Weston \& Copeland, 1997).

Variabel bebas (independent), yaitu variabel yang menjadi sebab perubahan atau yang mempengaruhi variabel terikat (dependent) (Sugiyono, 2013:59). Variabel bebas dalam penelitian ini adalah likuiditas, pertumbuhan penjualan, dan risiko bisnis. Likuiditas $\left(\mathrm{X}_{1}\right)$ merupakan kemampuan suatu perusahaan untuk 
ISSN: 2302-8556

memenuhi kewajiban keuangannya dalam jangka pendek atau yang segera jatuh tempo. Perusahaan dengan likuiditas yang tinggi cenderung menggunakan sumber dana internalnya terlebih dahulu sebelum menggunakan utang atau menerbitkan saham baru. Likuiditas adalah salah satu faktor yang menentukan sukses atau gagalnya suatu perusahaan penyediaan kebutuhan uang tunai untuk memenuhi kebutuhan jangka pendek. Perusahaan yang mampu memenuhi kewajiban finansialnya secara tepat waktu berarti perusahaan dalam keadaan likuid dan perusahaan tersebut punya alat pembayaran atau pun aktiva yang lebih besar dari hutang lancarnya. Jadi, dengan melihat likuiditas suatu perusahaan pihak kreditur juga dapat menilai baik buruknya suatu perusahaan tersebut (Jantana, 2013). Pada penelitian ini, likuiditas diproksikan dengan current ratio.

Pertumbuhan penjualan $\left(\mathrm{X}_{2}\right)$ menunjukkan perkembangan perusahaan. Suatu perusahaan yang mempunyai pertumbuhan penjualan tinggi mencerminkan perkembangan perusahaan tersebut tinggi (Barton et al. 1989) dalam (Mardiyati et $a l$, 2015). Pertumbuhan penjualan yang tinggi maka akan mencerminkan pendapatan meningkat sehingga pembayaran deviden cenderung meningkat. Apabila pertumbuhan penjualan perusahaan positif dan semakin meningkat, maka akan mengindikasikan nilai perusahaan yang besar, yang merupakan harapan dari pemilik perusahaan (Sukaria, 2015). Pada penelitian ini, pertumbuhan penjualan diproksikan dengan membandingkan penjualan pada tahun ke-t setelah dikurangi pejualan periode sebelumnya terhadap penjualan pada periode sebelumnya. 
Risiko bisnis $\left(\mathrm{X}_{3}\right)$ merupakan ketidakpastian yang dihadapi perusahaan dalam menjalankan kegiatan bisnisnya. Nilai perusahaan yang memiliki risiko bisnis yang tinggi karena keputusan pendanaan yang dipilihnya, akan turun di mata investor ketika terjadi risiko kebangkrutan. Konsekuensinya, kebanyakan aset perusahaan akan dijual untuk melunasi hutang yang jumlahnya besar dibandingkan untuk mengembalikan nilai saham yang ditanamkan investor. Perusahaan yang mempunyai risiko bisnis yang tinggi lebih baik menggunakan hutang yang lebih kecil (Vilalonga dan Amit, 2004). Pada penelitian ini, risiko bisnis dapat diukur dengan standar deviasi Earning Before Interest and Tax (EBIT) dibagi total aset (Titman and Wessels, 1988). Standar deviasi dari EBIT diukur dengan menggunakan data keuangan perusahaan 6 (enam) tahun sebelumnya (Furaida, 2010).

Jenis data yang digunakan dalam penelitian ini adalah data kuantitatif. Data kuantitatif adalah data dalam bentuk angka-angka atau data kualitatif yang telah diubah ke dalam angka (Sugiyono, 2013). Data kuantitatif dalam penelitian ini yaitu data laporan tahunan (annual report) perusahaan telekomunikasi yang terdaftar di Bursa Efek Indonesia periode 2011-2016 yang diperoleh melalui website www.idx.co.id.

Sumber data yang digunakan dalam penelitian ini adalah data sekunder. Sugiyono (2013) menyatakan data sekunder adalah data yang diperoleh dalam bentuk yang sudah ada, sudah dikumpulkan, dan diolah oleh pihak lain. Sumber data sekunder digunakan dalam penelitian dengan alasan tidak memungkinkan 
ISSN: 2302-8556

bagi peneliti untuk memperoleh data secara langsung. Sumber yang digunakan dalam penelitian ini adalah sumber data sekunder yang diperoleh dari laporan tahunan (annual report) perusahaan telekomunikasi yang terdaftar di Bursa Efek Indonesia periode 2011-2016.

Populasi merupakan suatu wilayah generalisasi yang terdiri atas objek atau subjek yang mempunyai kualitas dan karakteristik tertentu yang ditetapkan oleh peneliti untuk dipelajari dan kemudian ditarik kesimpulannya (Sugiyono, 2014:115). Populasi dari penelitian ini adalah semua perusahaan telekomunikasi yang terdaftar di Bursa Efek Indonesia (BEI) pada periode 2011-2016.

Sampel adalah bagian dari jumlah dan karakteristik yang dimiliki oleh populasi (Sugiyono, 2014:116). Metode penentuan sampel yang digunakan dalam penelitian ini adalah metode purposive sampling. Metode purposive sampling adalah teknik pengambilan sampel sumber data dengan kriteria yang telah ditentukan (Sugiyono, 2014:116). Pemilihan sampel dilakukan dengan menggunakan metode purposive sampling dengan tujuan mendapatkan sampel yang representatif sesuai dengan kriteria yang ditentukan dalam penelitian ini.

Metode pengumpulan data yang digunakan dalam penelitian ini adalah metode observasi nonpartisipan. Observasi nonpartisipan adalah observasi yang dilakukan tanpa melinatkan diri dan hanya sebagai pengamat independen. Dalam penelitian ini, data dikumpul dengan cara mencatat, mengamati, mempelajari serta menganalisis data-data dalam bentuk laporan tahunan (annual report) perusahaan 
telekomunikasi yang terdaftar di Bursa Efek Indonesia untuk periode 2011-2016 yang diperoleh dengan mengakses Bursa Efek Indonesia melalui www.idx.co.id.

Penelitian ini menggunakan teknik analisis regresi linier berganda untuk pengolahan dengan bantuan program SPSS. Teknik ini digunakan untuk mengetahui pengaruh antara empat variabel dalam penelitian, yaitu Likuiditas, Pertumbuhan Penjualan, dan Risiko Bisnis terhadap Nilai Perusahaan pada perusahaan telekomunikasi yang terdaftar di Bursa Efek Indonesia periode 20112016. Persamaan regresi dalam penelitian ini adalah :

$\mathrm{Y}=\alpha+\beta_{1} \mathrm{X}_{1}+\beta_{2} \mathrm{X}_{2}+\beta_{3} \mathrm{X}_{3}+\mathrm{e}$

Keterangan:

$\mathrm{Y}=$ Nilai Perusahaan

$\alpha \quad=$ Konstanta

$\beta=$ Koefisien Regresi

$\mathrm{X}_{1}=$ Likuiditas

$\mathrm{X}_{2}=$ Pertumbuhan Penjualan

$\mathrm{X}_{3}=$ Risiko Bisnis

$\mathrm{e}=$ Error

\section{HASIL DAN PEMBAHASAN}

Statistik deskriptif digunakan untuk memberikan gambaran dari suatu data yang dilihat dari jumlah sampel, nilai minimum, nilai maksimum, nilai rata-rata (mean), dan standar deviasi dari masing-masing variabel di dalam penelitian. Berdasarkan data olahan SPSS yang meliputi variabel likuiditas, pertumbuhan penjualan, risiko bisnis dan nilai perusahaan, didapat hasil analisis data untuk statistik deskriptif yang dapat dilihat pada tabel 2. 
ISSN: 2302-8556

Tabel 2.

Hasil Statistik Deskriptif

\begin{tabular}{lccccc}
\hline & N & Minimum & Maximum & Mean & Std. Deviation \\
\hline Likuiditas $\left(\mathrm{X}_{1}\right)$ & 30 & 0,08 & 1,49 & 0,7054 & 0,46786 \\
Pertumbuhan Penjualan $\left(\mathrm{X}_{2}\right)$ & 30 & $-0,66$ & 0,55 & 0,0247 & 0,25378 \\
Risiko Bisnis $\left(\mathrm{X}_{3}\right)$ & 30 & 0,01 & 1,80 & 0,1156 & 0,32437 \\
Nilai Perusahaan (Y) & 30 & $-1,11$ & 2,01 & 0,6250 & 0,62709 \\
Valid N & 30 & & & & \\
(listwise) & & & & &
\end{tabular}

Sumber: Data diolah, 2017

Berdasarkan tabel 2. dapat disimpulkan bahwa jumlah pengamatan (N) pada penelitian ini adalah sebanyak 30. Variabel likuiditas $\left(X_{1}\right)$ memiliki nilai minimum sebesar 0,08 dan nilai maksimum sebesar 1,49 dengan nilai rata-rata sebesar 0.7054. Standar deviasi pada variabel likuiditas adalah sebesar 0,46786. Variabel pertumbuhan penjualan $\left(\mathrm{X}_{2}\right)$ memiliki nilai minimum sebesar $-0,66$ dan nilai maksimum sebesar 0,55 dengan nilai rata-rata sebesar 0.0247. Standar devisiasi pada variabel pertumbuhan penjualan adalah sebesar 0,25378. Variabel risiko bisnis $\left(\mathrm{X}_{3}\right)$ memiliki nilai minimum sebesar 0.01 dan nilai maksimum sebesar 1.80 dengan nilai rata-rata sebesar 0.1156. Standar devisiasi pada variabel risiko bisnis adalah sebesar 0,32437 . Variabel nilai perusahaan (Y) memiliki nilai minimum sebesar $-1,11$ dan nilai maksimum sebesar 2,01 dengan nilai rata-rata sebesar 0,6250. Standar devisiasi pada variabel nilai perusahaan adalah sebesar 0,62709 .

Uji asumsi klasik yang dilakukan pada penelitian ini meliputi uji normalitas, uji autokorelasi, uji multikolienaritas, dan uji heteroskedastisitas. Uji normalitas dengan menggunakan uji non parametrik satu sampel Kolmogorov-Smirnov bertujuan untuk meyakinkan apakah residual dapat terdistribusi dengan normal dan independen. Hasil uji normalitas pada penelitian ini menunjukkan nilai 
Asymp. Sig (2-tailed) sebesar 0,200. Karena Asymp. Sig (p-value) 0,200 lebih besar daripada $\alpha(0,05)$ maka dapat diinterpretasikan bahwa residual dari model telah berdistribusi normal.

Model regresi yang baik adalah model yang tidak mengalami multikolinearitas. Dalam penelitian ini untuk mendeteksi gejala multikolinieritas dilakukan dengan melihat nilai Variance Inflation Factor (VIF). Hasil uji multikolinearitas pada penelitian ini menunjukkan bahwa nilai tolerance variabel bebas tidak ada yang kurang dari 10 persen $(0,1)$ dan seluruh variabel bebas memiliki nilai VIF kurang dari 10. Sehingga dapat disimpulkan bahwa pada data penelitian ini, tidak terjadi multikolinearitas antara variabel bebas dalam model regresi ini.

Pengujian heteroskedastisitas bertujuan untuk mengetahui apakah dalam model regresi terjadi ketidaksamaan varian dari residual satu pengamatan ke pengamatan lain. Hasil uji heteroskedastisitas pada penelitian ini menunjukkan bahwa tidak ada pengaruh variabel bebas $\left(\mathrm{X}_{1}, \mathrm{X}_{2}\right.$ dan $\left.\mathrm{X}_{3}\right)$ terhadap absolute residual (abs_res), baik secara serempak maupun parsial karena nilai Sig. lebih besar dari 0,05. Dengan demikian model yang dibuat tidak mengandung gejala heteroskedastisitas, sehingga layak digunakan untuk memprediksi.

Pengujian autokorelasi bertujuan untuk mengetahui apakah dalam model regresi linier ada korelasi antara kesalahan pengganggu pada periode $t$ dengan kesalahan pengganggu pada periode t-1 (sebelumnya) (Ghozali, 2012), jika terjadi korelasi dinamakan ada masalah autokorelasi. Uji autokorelasi dapat digunakan 
ISSN: 2302-8556

dengan Uji Durbin-Watson (DW-Test) (Ghozali, 2012). Hasil uji autokorelasi pada penelitian ini diperoleh nilai $d u=1,65$ dan $d l=1,514$. Jika $d u<d<(4-d u)$ maka nilai tersebut adalah $1,65<1,819<2,35$ sehingga tidak terjadi autokorelasi.

Tabel 3.

Hasil Analisis Regresi Linear Berganda

\begin{tabular}{llllll}
\hline \multirow{2}{*}{ Koefisien } & \multicolumn{2}{l}{$\begin{array}{l}\text { Unstandardized } \\
\text { Coefficients }\end{array}$} & $\begin{array}{l}\text { Standardized } \\
\text { Coefficients }\end{array}$ & \multirow{2}{*}{ t } & \multirow{2}{*}{ Signifikansi } \\
\cline { 2 - 5 } & B & Std. Error & Beta & & \\
\hline Konstanta $(\mathrm{a})$ & 0.317 & 0,150 & & 2,107 & 0,045 \\
likuiditas $\left(\mathrm{x}_{1}\right)$ & 0,522 & 0,171 & 0,390 & 3,059 & 0,005 \\
Pertumbuhan & 1,015 & 0,306 & 0,411 & 3,314 & 0,003 \\
penjualan $\left(\mathrm{X}_{2}\right)$ & & & & & \\
Risiko Bisnis $\left(\mathrm{x}_{3}\right)$ & $-0,736$ & 0,246 & $-0,380$ & $-2,995$ & 0,006 \\
F hitung & $:$ & 13,478 & & & \\
Signifikansi F & $:$ & 0,000 & & & \\
R Square & $:$ & 0,609 & & & \\
Adjusted R Square & $:$ & 0,563 & & &
\end{tabular}

Hasil analisis kelayakan model $\mathrm{F}$ dapat dilihat pada Tabel 3. menunjukkan bahwa nilai $\mathrm{F}$ hitung sebesar 13,478 dengan nilai signifikansi uji $\mathrm{F}$ yaitu sebesar 0,000 lebih kecil dari 0,05 yang berarti $\mathrm{H}_{1}$ diterima dan $\mathrm{H}_{0}$ ditolak. Hasil ini memberikan makna bahwa variabel likuiditas, pertumbuhan penjualan dan risiko bisnis dapat atau layak digunakan untuk memprediksi variabel nilai perusahaan

Koefisien determinasi (Adjusted $\mathrm{R}^{2}$ ) bertujuan untuk mengukur seberapa jauh kemampuan model dalam menerangkan variasi variabel dependen. Besarnya nilai Adjusted $R^{2}$ adalah sebesar 0,563 . Hal ini berarti bahwa 56,3 persen variasi besarnya nilai perusahaan dapat dijelaskan oleh variable likuiditas, pertumbuhan penjualan dan risiko bisnis. Sedangkan sisanya sebesar 43,7 persen dipengaruhi oleh variabel-variabel lain diluar model penelitian. 
Nilai t hitung pada likuiditas adalah sebesar 3,059 dengan tingkat signifikansi 0,005. Dengan menggunakan batas signifikansi 0,05 maka signifikansi tersebut dibawah taraf 5 persen yang berarti $\mathrm{H}_{0}$ ditolak dan $\mathrm{H}_{1}$ diterima. Hal ini menunjukkan bahwa likuiditas berpengaruh positif pada nilai perusahaan. Koefisien regresi variabel likuiditas $\left(\mathrm{X}_{1}\right)$ 0,522. Hal ini berarti bahwa apabila variabel likuditas $\left(\mathrm{X}_{1}\right)$ meningkat satu satuan, maka akan mengakibatkan peningkatan pada nilai perusahaan sebesar 0,522, dengan asumsi variabel bebas lainnya dianggap konstan.

Hasil analisis menunjukan koefisien regresi likuiditas memiliki tanda positif. Hal ini menjukan bahwa semakin tinggi likuiditas yang terjadi pada perusahaan tersebut akan menyebabkan nilai perusahaan semakin meningkat ataupun sebaliknya yaitu semakin rendah likuiditas yang terjadi pada perusahaan maka semakin rendah nilai perusahaan tersebut. Hasil ini mendukung $\left(\mathrm{H}_{1}\right)$ yang menyatakan bahwa likuiditas berpengaruh positif terhadap nilai perusahaan. Dengan demikian perusahaan yang mampu memenuhi kewajiban keuangannya tepat waktu berarti perusahaan tersebut dalam keadaan likuid sehingga akan mempengaruhi investor untuk berinvestasi pada perusahaan yang akan mengakibatkan permintaan saham meningkat serta peningkatan harga saham dan nilai perusahaan.

Hasil penelitian ini juga didukung oleh Menawati (2017) menemukan pengaruh positif likuiditas terhadap nilai perusahaan. Bila perusahaan mampu memelihara likuiditasnya dengan baik, maka kegiatan operasional perusahaan 
ISSN: 2302-8556

dapat berjalan dengan baik dan dapat memberikan dampak yang positif pada perusahaan.

Nilai t hitung pada variabel pertumbuhan penjualan adalah sebesar 3,314 dengan tingkat signifikansi 0,003 . Dengan menggunakan batas signifikansi 0,05 maka signifikansi tersebut dibawah taraf 5 persen yang berarti $\mathrm{H}_{0}$ ditolak dan $\mathrm{H}_{2}$ diterima. Hal ini menunjukkan bahwa pertumbuhan penjualan berpengaruh positif pada nilai perusahaan. Koefisien regresi variabel pertumbuhan penjualan $\left(\mathrm{X}_{2}\right)$ 1,015. Hal ini berarti bahwa apabila variabel pertumbuhan penjualan $\left(X_{2}\right)$ meningkat satu satuan, maka akan mengakibatkan peningkatan pada nilai perusahaan sebesar 1,015 dengan asumsi variabel bebas lainnya dianggap konstan.

Hasil analisis menunjukan koefisien regresi pertumbuhan penjualan memiliki tanda positif. Hal ini menunjukan bahwa semakin tinggi grafik pertumbuhan penjualan perusahaan menyebabkan peningkatan terhdap nilai perusahaan ataupun sebaliknya yaitu semakin rendah grafik penjualan perusahaan maka akan terjadi penurunan terhadap nilai perusahaan. Hasil ini mendukung $\left(\mathrm{H}_{2}\right)$ yang menyatakan bahwa pertumbuhan penjualan yang berpengaruh positif pada nilai perusahaan. Dengan demikian apabila suatu perusahaan yang mempunyai pertumbuhan penjualan yang tinggi mencerminkan perkembangan perusahaan tersebut tinggi. Pertumbuhan penjualan yang tinggi maka akan mencerminkan pendapatan meningkat sehingga pembayaran deviden cenderung meningkat sehingga investor akan berminat membeli saham perusahaan tersebut dan akan 
mengakibatkan peningkatan pada nilai sebuah perusahaan yang mengalami pertumbuhan penjualan.

Hasil penelitian ini juga konsisten dengan penelitian yang dilakukan Sukaria (2015) menyatakan bahwa pertumbuhan penjualan berpengaruh positif terhadap nilai perusahaan. Hal ini berarti semakin tingggi pertumbuhan penjualan maka nilai perusahaan semakin meningkat atau sebaliknya semakin rendah pertumbuhan penjualan semakin rendah nilai perusahaan.

Nilai t hitung pada variabel risiko bisnis adalah sebesar -2,995 dengan tingkat signifikansi 0,006. Dengan menggunakan batas signifikansi 0,05 maka signifikansi tersebut dibawah taraf 5 persen yang berarti $\mathrm{H}_{0}$ ditolak dan $\mathrm{H} 3$ diterima. Hal ini menunjukkan bahwa risiko bisnis berpengaruh negatif pada nilai perusahaan. Koefisien regresi variabel pertumbuhan penjualan $\left(\mathrm{X}_{2}\right)-0,736$. Hal ini berarti bahwa apabila variabel risiko bisnis $\left(\mathrm{X}_{3}\right)$ meningkat satu satuan, maka akan mengakibatkan penurunan pada nilai perusahaan sebesar 0,736 dengan asumsi variabel bebas lainnya dianggap konstan.

Hasil analisis menunjukan koefisien regresi risiko bisnis memiliki tanda negatif. Hal ini menunjukan bahwa semakin tinggi sebuah risiko bisnis akan menyebabkan nilai sebuah menurun ataupun sebaliknya yaitu semakin rendah suatu risiko bisnis maka semakin tinggi nilai perusahaan tersebut. Hasil ini mendukung $\left(\mathrm{H}_{3}\right)$ yang menyatakan bahwa risiko bisnis yang berpengaruh negatif terhadap nilai. Hal ini disebabkan karena risiko bisnis menyebabkan ketidakpastian dalam proyeksi perusahaan atas tingkat pengembalian atau laba di 
ISSN: 2302-8556

masa mendatang. Risiko bisnis yang besar menyebabkan kreditur enggan memberikan pinjaman dan investor juga enggan untuk menanamkan modal diperusahaan yang memiliki risiko bisnis yang besar karena kekhawatiran bahwa perusahaan tersebut tidak mempu memenuhi kewajibannya dimasa mendatang, akibat hal tersebut akan menyebabkan harga saham yang menurun sehingga akan berdampak pada nilai perusahaan yang rendah.

Hasil penelitian ini juga konsisten dengan penelitian yang dilakukan oleh Efni (2011), serta Pagach dan Warr (2010), risiko bisnis mempunyai pengaruh negatif terhadap nilai perusahaan. Hal ini berarti bahwa semakin meningkat risiko bisnis perusahaan maka nilai perusahaan akan semakin menurun.

\section{SIMPULAN}

Berdasarkan pembahasan hasil penelitian terhadap variabel-variabel bebas yang mempengaruhi nilai perusahaan yang diukur dengan variabel likuiditas, pertumbuhan penjualan dan risiko bisnis dapat disimpulkan sebagai berikut: 1) Likuditas mempunyai pengaruh positif terhadap nilai perusahaan. Semakin tinggi kemungkinan perusahaan mampu melunasi kewajibannya maka akan menyebabkan nilai perusahaan yang terus meningkat; 2) Pertumbuhan penjualan mempunyai pengaruh positif terhadap nilai perusahaan. Semakin tinggi pertumbuhan penjualan suatu perusahaan maka investor akan tertarik menanamkan modal di perusahaan tersebut yang akan mengakibatkan peningkatan terhadap nilai perusahaan; 3) Risiko bisnis mempunyai pengaruh negatif terhadap nilai perusahaan. Semakin tinggi risiko bisnis perusahaan 
tersebut maka akan menyebabkan penurunan terhadap nilai perusahaan karena kekhawatiran investor untuk menanamkan modal di perusahaan akibat ketidak pastian perusahaan dalam memenuhi kewajibannya.

Saran bagi peneliti selanjutnya diharapkan mengembangkan penelitian ini dengan menambahkan variabel yang mempengaruhi nilai perusahaan seperti profitabilitas, ukuran perusahaan, pertumbuhan aset, struktur modal dan lain-lain yang tidak diteliti oleh peneliti.

\section{REFERENSI}

Arif. (2015). Pengaruh Struktur Modal, Return on Equity, Likuiditas, dan Growth Opportunity Terhadap Nilai Perusahaan pada Perusahaan Jasa yang Terdaftar di Bursa Efek Indonesia. Skripsi. Yogyakarta: Universitas Negeri Yogyakarta.

Alfi, Shohreh., Mohammad, Safarzadeh. (2016). Effect Of Capital Structure And Liquidity On Firm Value. I J A B E R, 14(14), pp: 10143-10153.

Bhattacharya, S. (1979). Imperfect Information, Dividend Policy and The Bird in. The Hand Fallacy. Journal of Economics, Vol. 10, No. 1, Hal: 259270.

Bayless, Mark E., dan J. David Diltz. (1994). Security Offering and Capital Structure Theory. Journal of Business Finance \& Accounting, 21 (1), pp: 77-91.

Brigham, Eugene., dan Joel F. Houston. (2006). Dasar-Dasar Manajemen Keuangan Edisi 10. Jakarta: Salemba Empat.

Efni, Y., D. Hadiwidjojo, U. Salim, dan M. Rahayu. (2012). Keputusan Investasi, Keputusan Pendanaan dan Dividen: Pengaruh Terhadap Nilai Perusahaan (Studi pada Sub Sektor Property dan Real Estate di Bursa Efek Indonesia). Jurnal Aplikasi Manajemen, 10 (1), h: 128-141.

Ghozali, Imam. (2012). Aplikasi Analisis Multivariate dengan Program SPSS. Edisi Kedua. Semarang: Universitas Diponogoro. 
ISSN: 2302-8556

Harahap, Sofyan S. (2010). Analisis Kritis atas Laporan Keuangan, Edisi 9. Jakarta: Grafindo Persada.

Jantana, Indra. (2013). Pengaruh Struktur Modal, Profitabilitas, dan Likuiditas Terhadap Nilai Perusahaan pada Perusahaan Sektor Barang Konsumsi Sub Sektor Rokok di BEI Tahun 2007-2011. Jurnal Akuntansi dan Bisnis.

Joni dan Lina. (2010). Faktor-faktor yang Mempengaruhi Struktur Modal. Jurnal Bisnis dan Akuntansi, 12 (2), h: 81-96.

Mahendra, Alfredo. (2011). Pengaruh Kinerja Keuangan Terhadap Nilai Perusahaan (Kebijakan Dividen sebagai Pemoderasi) pada Perusahaan Manufaktur di Bursa Efek Indonesia. Tesis. Denpasar: Universitas Udayana.

Mardiyati, Umi, Gatot Nazir Ahmad dan Muhammad Abrar. (2015). Pengaruh Keputusan Investasi, Keputusan Pendanaan, Ukuran Perusahaan dan Profitabilitas Terhadap Nilai Perusahaan pada Sektor Manufaktur Barang Konsumsi yang Terdaftar di Bursa Efek Indonesia Periode 2010-2013. Jurnal Riset Manajemen Sains Indonesia (JRMSI), 6 (1), h: 417-439.

Menawati, Ni Made Wiwik. (2017). Pengaruh Rentabilitas dan Likuiditas pada Jumlah Opsi Saham dan Dampaknya pada Nilai Perusahaan. E-Jurnal Akuntansi Universitas Udayana Vol.18.3. Maret (2017): 1915-1942.

Munawir, S. 2001. Analisis Laporan Keuangan, Edisi 10. Yogyakarta: Liberti.

Pagach, D., and Richard Warr. (2010). The Effect of Enterprise Risk Management on Firm Performance. Journal of Jenkins Graduate School of Management, North Carolina State University.

Riyanto, Bambang. (2001). Dasar-Dasar Pembelanjaan Perusahaan Edisi 4. Yogyakarta: BPFE.

Sucuahi,William., Jay, Cambarihan. (2016). Influence of Profitability to the Firm Value of Diversified Companies in the Philippines. Accounting and Finance Research, 5(2), pp: 149-153.

Sugiyono. (2013). Metode Penelitian Pendidikan Pendekatan Kuantitatif, Kualitatif dan R\&D. Bandung: Alfabeta.

Sukaria, Nova. (2015). Pengaruh Ukuran Perusahaan, Pertumbuhan Penjualan, Profitabilitas dan Struktur Modal Terhadap Nilai Perusahaan Manufaktur 
Ida Ayu Puspita Trisna Dewi dan I Ketut Sujana. Pengaruh...

di Bursa Efek Indonesia, Jurnal Akuntansi, Universitas Muhammadiyah Yogyakarta.

Titman, Sheridan dan Roberto Wessels. (1988). The Determinants of Capital Structure Choice. The Journal of Finance, 43 (1), pp: 1-19

Van Horne, James C., dan John M. Wachowicz, Jr. (1998). Prinsip-Prinsip Manajemen Keuangan. Jakarta: Salemba Empat.

Weston, Fred J. (1996). Manajemen Keuangan, Edisi 8, Jilid 2. Bina Rupa

Weston, Fred J., dan Eugene F. Brigham. (1990). Manajemen Keuangan. Edisi Ketujuh, Jilid 2. Jakarta: Erlangga.

Weston, Fred J., dan Thomas E. Copeland. (1997). Manajemen Keuangan, Jilid 2 Edisi 9. Jakarta: Binarupa Aksara.

Wiagustini, Ni Luh Putu. (2010). Dasar-Dasar Manajemen Keuangan. Denpasar: Udayana University Press. 